\title{
PENGARUH MODEL PROBLEM BASED LEARNING TERHADAP KEMAMPUAN BERPIKIR KRITIS MATEMATIS PESERTA DIDIK KELAS VIII SMP NEGERI 2 KENDARI
}

\author{
Dino Steven ${ }^{1)}$, La Ndia ${ }^{2}$, La Arapu ${ }^{3)}$ \\ 1) Alumni Jurusan Pendidikan Matematika, ${ }^{2,3)}$ Dosen Jurusan Pendidikan Matematika \\ FKIP Universitas Halu Oleo. Email: steven.dino@yahoo.com; \\ landia.fkipmat@yahoo.com; laarapu@gmail.com
}

\begin{abstract}
Abstrak
Penelitian ini bertujuan untuk mengetahui pengaruh model Problem Based Learning terhadap kemampuan berpikir kritis matematis peserta didik kelas VIII SMP Negeri 2 Kendari. Populasi dalam penelitian ini melibatkan seluruh peserta didik kelas VIII SMP Negeri 2 Kendari tahun pelajaran 2018/2019 yang terdistribusi dalam 9 kelas. Penentuan sampel dalam penelitian ini dilakukan dengan menggunakan teknik Purposive Sampling. Dari cara tersebut, dipilih 2 kelas sebagai sampel, yakni kelas VIII-D sebagai kelas ekperimen yang diterapkan model Problem Based Learning dan kelas VIII-C sebagai kelas kontrol yang diterapkan model pembelajaran langsung. Desain penelitian menggunakan Posttest Only Control Group Design. Data hasil penelitian dikumpulkan melalui pemberian instrumen berupa tes kemampuan berpikir kritis matematis berbentuk soal uraian dan lembar observasi. Teknik analisis data menggunakan statistik deskriptif dan statistik inferensial. Berdasarkan hasil penelitian, diperoleh kesimpulan terdapat pengaruh yang signifikan model Problem Based Learning terhadap kemampuan berpikir kritis matematis peserta didik di kelas VIII SMP Negeri 2 Kendari.
\end{abstract}

Kata Kunci: model pembelajaran, problem based learning, kemampuan berpikir kritis

\section{EFFECT OF PROBLEM BASED LEARNING MODEL ON MATHEMATICAL CRITICAL THINGKING ABILITIES OF CLASS VIII STUDENTS OF SMP NEGERI 2 KENDARI}

\begin{abstract}
This study aims to determine the effect of Problem Based Learning models on mathematical critical thinking skills of class VIII students of SMP Negeri 2 Kendari. The population in this study involved all class VIII students of SMP Negeri 2 Kendari in 2018/2019 academic year distributed in 9 classes. Determination of samples in this study was carried out using Purposive Sampling techniques. From this method, 2 classes were selected as samples, namely class VIII-D as the experimental class that applied the Problem Based Learning model and class VIII-C as the control class which applied the direct learning model. The research design uses Posttest Only Control Group Design. Data from research results were collected through the provision of instruments in the form of tests of mathematical critical thinking abilities in the form of description questions and observation sheets. The data analysis technique uses descriptive statistics and inferential statistics. Based on the results of the study, concluded that there is a significant effect of the Problem Based Learning model on students' mathematical critical thinking abilities in class VIII of SMP Negeri 2 Kendari.
\end{abstract}

Keywords: learning model, problem based learning, critical thingking skill 


\section{Pendahuluan}

Pelaksanaan program wajib belajar dapat dipandang sebagai salah satu bentuk peningkatan kualitas sumber daya manusia di Indonesia, termasuk kualitas berpikirnya. Salah satu fungsi pendidikan adalah menyiapkan generasi mendatang yang lebih baik. Jika kehidupan yang akan datang sarat dengan problematika dan tantangan yang semakin kompleks, maka pendidikan harus menyiapkan generasi yang mampu menjawab tantangan dan problematika yang dihadapinya, yakni menyiapkan generasi yang berkepribadian unggul, terampil dan kritis (Nahdi, 2015: 14). Oleh karena itu Guru perlu membekali kemampuan berpikir kritis peserta didiknya. Hal ini dikarenakan peserta didik yang hanya mempelajari materi saja tanpa dibekali kemampuan ini akan mengalami kesulitan ketika bekerja pada bagian aktivitas mencari dan menganalisis informasi. Menurut Anderson, bila berpikir kritis dikembangkan, seseorang akan cenderung untuk mencari kebenaran, berpikir divergen (terbuka dan toleran terhadap ide-ide baru), dapat menganalisis masalah dengan baik, berpikir secara sistematis, penuh rasa ingin tahu, dewasa dalam berpikir, dan dapat berpikir secara mandiri (Lestari, 2013: 2). Sehingga kemampuan berpikir kritis menjadi hal yang sangat penting untuk dikuasai peserta didik saat ini.

Studi yang dilaksanakan oleh Trends in International Mathematics and Science Study (TIMSS), sebuah lembaga internasional yang mengukur hasil pendidikan di dunia yang dilakukan kepada peserta didik SMP dengan karakteristik soal-soal level kognitif tinggi. Pada tahun 2015, peringkat Indonesia dibidang matematika hanya berada diposisi 45 dari jumlah peserta seluruhnya yakni 50 negara. Dalam studi tersebut, Indonesia hanya menempati skor 397 jauh di bawah rata-rata skor internasional yaitu 500. Dari studi tersebut terungkap bahwa peserta didik Indonesia masih lemah dalam menyelesaikan soal-soal tidak rutin yang berkaitan dengan pembuktian, pemecahan masalah yang memerlukan penalaran matematika, menemukan generalisasi atau konjektur, dan menemukan hubungan antara data-data atau fakta yang diberikan. Berdasarkan fakta di atas, dapat dikatakan bahwa kemampuan pemecahan masalah, kemampuan berpikir kritis, kreatif dan reflektif peserta didik pada umumnya masih rendah.

Hasil Program for International
Students Assessment (PISA) yang diselenggarakan pada tahun 2015, Indonesia menduduki posisi ke-63 dari 70 negara untuk bidak studi matematika. Kemampuan dalam bidang matematika Indonesia menunjukkan skor yang rendah, yaitu 386. Padahal soal-soal matematika dalam PISA mengukur kemampuan komunikasi, menalar, representasi, pemecahan masalah, berargumentasi, berkomunikasi dan berpikir tingkat tinggi. Berdasarkan fakta tersebut, maka dapat dikatakan bahwa kemampuan berpikir kritis peserta didik SMP di Indonesia masih sangat rendah.

Hal ini juga merupakan salah satu permasalahan yang ditemukan peneliti di SMP Negeri 2 Kendari. Berdasarkan keterangan yang diperoleh dari guru mata pelajaran matematika kelas VIII SMP Negeri 2 Kendari, rata-rata hasil penilaian tengah semester (PTS) yang dilakukan pada bulan Oktober 2018 dikelas VIII sebesar 62,44 dimana $73,99 \%$ dari jumlah siswa memiliki nilai dibawah KKM (72) dan 50,46\% dari jumlah siswa memiliki nilai di bawah ratarata. Hasil belajar yang rendah tentu akan mempengaruhi kemampuan berpikir tingkat tinggi peserta didik, salah satunya adalah kemampuan berpikir kritis. Hal ini memperlihatkan bahwa kemampuan berpikir kritis matematis peserta didik kelas VIII di SMP Negeri 2 Kendari masih rendah.

Rendahnya kemampuan berpikir kritis matematis peserta didik kelas VIII SMP Negeri 2 Kendari juga terlihat dari hasil pengamatan peneliti pada lembar jawaban peserta didik dalam menjawab LKPD yang diberikan guru dalam pembelajaran matematika. Ketika menyelesaikan soal uraian, terlihat bahwa peserta didik tidak menuliskan apa yang diketahui dan ditanyakan, tidak menuliskan konsep yang berkaitan dan tidak mengevaluasi solusi atau jawaban yang telah diperoleh. Sehingga indikator-indikator kemampuan berpikir kritis tidak terpenuhi yang menyebabkan kemampuan berpikir kritis matematis peserta didik kelas VIII SMP Negeri 2 Kendari menjadi rendah.

Salah satu model pembelajaran yang dapat meningkatkan kemampuan berpikir kritis matematis peserta didik adalah adalah model 
Problem Based Learning (PBL) atau pembelajaran berbasis masalah (PBM). Melalui model Problem Based Learning, peserta didik dihadapkan pada masalah yang penuh dengan makna dan peserta didik diharapkan mampu menggunakan dan mengembangkan kemampuan dasar yang dimilikinya dan berpikir tingkat tinggi termasuk diantaranya adalah berpikir kritis serta dapat menggunakan berbagai macam strategi untuk memecahkan suatu permasalahan. Melalui kegiatan ini aspek-aspek yang menunjukkan kemampuan matematika peserta didik seperti menghadapi masalah rutin maupun tidak, menemukan pola, menggeneralisasikan kesimpulan, komunikasi matematika, dan lainlain dapat dikembangkan dengan baik yaitu dengan mempertimbangkan gagasan peserta didik dan melibatkan peserta didik secara aktif dalam memecahkan masalah matematika.

Fokus pembelajaran dalam model Problem Based Learning ada pada masalah yang dipilih sehingga peserta didik tidak saja mempelajari konsep-konsep yang berhubungan dengan masalah tetapi juga metode ilmiah untuk memecahkan masalah tersebut. Oleh sebab itu, peserta didik tidak saja harus memahami konsep yang relevan dengan masalah yang menjadi pusat perhatian tetapi juga memperoleh pengalaman belajar yang berhubungan dengan keterampilan menerapkan metode ilmiah dalam pemecahan masalah dan menumbuhkan pola berpikir kritis.

Model Problem Based Learning (pembelajaran berbasis masalah) merupakan salah satu model pembelajaran yang berasosiasi dengan pembelajaran kontekstual. Menurut Husnidar, dkk., (2014: 75) pembelajaran berbasis masalah memberi pengertian bahwa dalam pembelajaran peserta didik dihadapkan pada suatu masalah, yang kemudian diharapkan melalui pemecahan masalah peserta didik belajar keterampilan-keterampilan berpikir yang lebih mendasar. Sedangkan menurut Saleh (2013: 203) Problem Based Learning adalah suatu model pembelajaran yang didasarkan pada prinsip menggunakan masalah sebagai titik awal dan integrasi pengetahuan baru. Problem Based Learning adalah salah satu model pembelajaran yang berpusat pada peserta didik dengan cara menghadapkan peserta didik tersebut dengan berbagai masalah yang dihadapi dalam kehidupannya. Jadi, model Problem Based Learning dapat mengembangkan keterampilan berpikir dan keterampilan memecahkan masalah yang dihadapi oleh peserta didik.

Tujuan utama Problem Based Learning adalah untuk menggali daya kreativitas peserta didik dalam berpikir dan memotivasi peserta didik untuk terus belajar. Dan harus diingat bahwa, model pembelajaran ini tidak dirancang untuk membantu guru memberikan informasi sebanyak-banyaknya kepada peserta didik, akan tetapi Problem Based Learning dikembangkan untuk membantu peserta didik mengembangkan kemampuan berfikir, pemecahan masalah, keterampilan intelektual, belajar berbagai peran orang dewasa melalui pelibatan mereka dalam pengalaman nyata atau simulasi dan menjadi pelajar yang mandiri. Tujuan dari model Problem Based Learning menurut Kurniasih dan Berlin (2017: 48) adalah: Membantu peserta didik mengembangkan keterampilan berfikir dan keterampilan pemecahan masalah, belajar peranan orang dewasa yang otentik, menjadi peserta didik yang mandiri, untuk bergerak pada level pemahaman yang lebih umum, membuat kemungkinan transfers pengetahuan baru, mengembangkan pemikiran kritis dan keterampilan kreatif, meningkatkan kemampuan pemecahan masalah, meningkatkan motivasi belajar peserta didik, membantu peserta didik belajar untuk mentransfer pengetahuan dengan 5 qujProblem Based Learning. Menurut Amir (2010: 22) karakteristik model problem based learning yaitu: (1) masalah digunakan sebagai awal pembelajaran, (2) masalah yang digunakan merupakan masalah dunia nyata yang disajikan secara mengambang, (3) masalah biasanya menuntut perspektif majemuk, (4) masalah membuat pelajar tertantang akan pengetahuan baru, (5) mengutamakan belajar mandiri, (6) memanfaatkan sumber pengetahuan yang bervariasi, dan (7) pembelajarannya kolaboratif, komunikatif, dan kooperatif.

Terdapat lima tahap utama dalam proses pembelajaran menggunakan model Problem Based Learning. Kelima tahapan tersebut disajikan dalam bentuk Tabel 1 . 
Tabel 1.

Sintaks Model Problem Based Learning

\begin{tabular}{|c|l|l|}
\hline No & \multicolumn{1}{|c|}{ Fase } & \multicolumn{1}{|c|}{ Aktifitas / Kegiatan Guru } \\
\hline 1 & $\begin{array}{l}\text { Memberikan orientasi } \\
\text { tentang permasalahan } \\
\text { kepada peserta didik }\end{array}$ & $\begin{array}{l}\text { Guru membahas tujuan pembelajaran, mendeskripsikan berbagai } \\
\text { kebutuhan logistik penting, dan memotivasi peserta didik untuk } \\
\text { terlibat dalam kegiatan mengatasi masalah. }\end{array}$ \\
\hline 2 & $\begin{array}{l}\text { Mengorganisasikan } \\
\text { peserta didik untuk } \\
\text { belajar }\end{array}$ & $\begin{array}{l}\text { Guru membantu peserta didik mendefenisikan dan } \\
\text { mengorganisasikan tugas-tugas belajar yang terkait dengan } \\
\text { permasalahannya. }\end{array}$ \\
\hline 3 & $\begin{array}{l}\text { Membantu penyelidikan } \\
\text { individu dan kelompok }\end{array}$ & $\begin{array}{l}\text { Guru mendorong peserta didik untuk mendapatkan informasi yang } \\
\text { tepat, melaksanakan eksperimen, dan mencari penjelasan, dan } \\
\text { solusi. }\end{array}$ \\
\hline 4 & $\begin{array}{l}\text { Mengembangkan dan } \\
\text { menyajikan hasil karya }\end{array}$ & $\begin{array}{l}\text { Guru membantu peserta didik dalam merencanakan dan menyiapkan } \\
\text { artefak-artefak yang tepat seperti laporan rekaman video, dan } \\
\text { model-model, dan membantu mereka untuk menyampaikannya pada } \\
\text { orang lain. }\end{array}$ \\
\hline 5 & $\begin{array}{l}\text { Menganalisis dan } \\
\text { mengevaluasi proses } \\
\text { pemecahan masalah }\end{array}$ & $\begin{array}{l}\text { Guru membantu peserta didik melakukan refleksi atau evaluasi } \\
\text { terhadap investigasinya dan proses-proses yang mereka gunakan. }\end{array}$ \\
\hline
\end{tabular}

(Arends, 2012: 411).

Model pembelajaran berbasis masalah ini memiliki keunggulan yang sangat banyak. Menurut Kurniasih dan Berlin (2017: 48) kelebihan model Problem Based Learning diantaranya adalah:

1. Mengembangkan pemikiran kritis dan keterampilan kreatif peserta didik.

2. Dapat meningkatkan kemampuan memecahkan masalah para peserta didik dengan sendirinya.

3. Meningkatkan motivasi peserta didik dalam belajar.

4. Membantu peserta didik belajar untuk mentransfer pengetahuan dengan situasi yang serba baru.

5. Dapat mendorong peserta didik mempunyai inisiatif untuk belajar secara mandiri.

6. Mendorong kreativitas peserta didik dalam pengungkapan penyelidikan masalah yang telah ia lakukan.

7. Dengan model pembelajaran ini akan terjadi pembelajaran yang bermakna.

8. Peserta didik mengintegrasikan pengetahuan dan keterampilan secara simultan dan mengaplikasikannya dalam konteks yang relevan.

9. Model pembelajaran ini dapat meningkatkan kemampuan berpikir kritis, menumbuhkan inisiatif peserta didik dalam bekerja, motivasi internal untuk belajar, dan dapat mengembangkan hubungan interpersonal dalam bekerja kelompok.
Meskipun model pembelajaran ini terlihat begitu baik dan sempurna dalam meningkatkan kemampuan berpikir peserta didik, tapi tetap saja memiliki celah kelemahan. Menurut Kurniasih dan Berlin (2017: 48) kelemahan model ini diantaranya adalah:

1. Model ini butuh pembiasaan, karena model itu cukup rumit dalam teknisnya serta peserta didik betul-betul harus dituntut konsentrasi dan daya kreasi yang tinggi.

2. Dengan mempergunakan model ini, berarti proses pembelajaran harus dipersiapkan dalam waktu yang cukup panjang. Karena sedapat mungkin setiap persoalan yang akan dipecahkan harus tuntas, agar maknanya tidak terpotong.

3. Peserta didik tidak benar-benar tahu apa yang mungkin penting bagi mereka untuk belajar, terutama bagi mereka yang tidak memiliki pengalaman sebelumnya.

4. Sering juga ditemukan kesulitan terletak pada guru, karena guru kesulitan menjadi fasilitator dan mendorong peserta didik untuk mengajukan pertanyaan yang tepat daripada menyerahkan mereka solusi.

Kemampuan berpikir merupakan hal yang sangat penting dalam pembelajaran matematika. Kemampuan berpikir atau yang sering disebut dengan thingking skill adalah kemampuan yang merujuk pada pemikiran seseorang, pemikiran dalam menilai kebaikan suatu ide, buah pikiran, pandangan, dan dapat 
memberikan respon berdasarkan kepada bukti dan sebab akibat. Menurut Nurohman dalam Junaidi (2017: 16-17) Thingking Skill adalah kemampuan seseorang dalam mendayagunakan kemampuan mentalnya untuk menyelesaikan berbagai persoalan dalam kehidupan nyata. Thingking Skill dapat dijabarkan menjadi beberapa indikator, antara lain: kemampuan menggali informasi, kemampuan mengelola informasi, dan kemampuan memutuskan suatu masalah berdasarkan informasi yang sudah diperoleh. Thingking Skill merupakan kemampuan seseorang untuk menggunakan aktivitas pikirannya secara terbatas dengan mengkombinasikan pemikiran pada saat berpikir. Kemampuan tersebut seperti mengingat sesuatu, membedakan antara sesuatu yang relvan dan tidak relevan, mengklasifikasi, memprediksi, menilai kekuatan suatu tuntutan, menyatakan sesuatu, menarik kesimpulan dan membuat keputusan. Kemampuan tersebut diguanakan terus menerus untuk memperoleh suatu pengertian atau pengetahuan.

Kemampuan berpikir kritis matematis merupakan satu kemampuan dasar matematis yang esensial dan perlu dimiliki oleh peserta didik yang belajar matematika. Menurut Elaine B Jhonson (Junaidi, 2017: 17) berpikir kritis adalah sebuah proses sistematis dan terorganisasi yang memungkinkan peserta didik dapat merumuskan dan mengevaluasi pendapat mereka sendiri atau berdasarkan bukti, asumsi, logika, dan bahasa yang mendasari pendapat orang lain sehingga mereka mampu mengungkapkan pendapat mereka sendiri dengan penuh percaya diri. Berpikir kritis membantu peserta didik mencapai pemahaman yang mendalam dan dapat mengambil kesimpulan secara cerdas terhadapap sebuah informasi, sehingga mereka mampu memecahkan masalah dengan menggunakan pemikiran yang sistematis dan logis.

Kemampuan berpikir kritis matematis merupakan satu kemampuan dasar matematis yang esensial dan perlu dimiliki oleh peserta didik yang belajar matematika. Menurut Hendriana, dkk., (2017: 95), terdapat beberapa alasan yang mendasari pernyataan tersebut. Pertama, kemampuan berpikir matematis termuat dalam kurikulum dan tujuan pembelajaran matematika, antara lain: melatih berpikir logis, sistematis, kritis, kreatif, dan cermat serta berpikir objektif, terbuka untuk menghadapi masalah dalam kehidupan sehari- hari serta untuk menghadapi masa depan yang selalu berubah. Kedua, dalam berpikir kritis, seseorang tidak dengan mudah menerima sesuatu yang diterimanya, tanpa mengetahui asalnya, namun ia dapat mempertanggung jawabkan pendapatnya disertai dengan alasan yang logis.

Ennis mengatakan terdapat enam elemen dasar dalam berpikir kritis yaitu: Focus (fokus), Reason (alasan), Inference (membuat pernyataan), Situation (situasi), Clarify (kejelasan) dan Overview (tinjau ulang). Penjelasan mengenai keenam dasar tersebut adalah sebagai berikut (Sujana dan Utu, 2013: 64).

a. Focus (fokus), yaitu hal pertama yang harus dilakukan untuk mengetahui informasi. Untuk fokus terhadap suatu permasalahan, diperlukan pengetahuan. semakin banyak pengetahuan yang dimiliki akan semakin mudah mengenali informasi.

b. Reason (alasan), yaitu mencari kebenaran dari pernyataan yang akan dikemukakan. Dalam mengemukakan pernyataan harus disertai alasan-alasan yang mendukung pernyataan tersebut.

c. Inference (membuat pernyataan), yaitu mengemukakan pendapat dengan alasan yang tepat.

d. Situation (situasi), yaitu kebenaran dari suatu pernyataan tergantung situasi yang terjadi. Oleh karena itu, perlu mengetahui situasi/keadaan permasalahan.

e. Clarify (kejelasan), yaitu memastikan kebenaran sebuah pernyataan dari situasi yang terjadi.

f. Overview (tinjauan ulang), yaitu melihat kembali sebuah proses dalam memastikan sebuah kebenaran pernyataan dalam situasi yang ada sehingga bisa menentukan keterkaitan dengan situasi lainnya.

Berpikir kritis adalah berpikir rasional dalam menilai sesuatu. Sebelum mengambil suatu keputusan atau melakukan suatu tindakan, maka dilakukan pengumpulan informasi sebanyak mungkin tentang sesuatu tersebut. Pada dasarnya kemampuan berpikir kritis erat kaitannya dengan proses berpikir kritis dan indikator-indikatornya. Indikator berpikir kritis dapat dilihat dari karakteristik-karakteristiknya sehingga dengan memiliki karakteristik tersebut seseorang dapat dikatakan telah memiliki kemampuan berpikir kritis. Facione mengungkapkan enam kecakapan berpikir kritis 
utama yang terlibat di dalam proses berpikir kritis (Karim dan Normaya, 2015: 93-94) yaitu:

1) Interpretasi. Menginterpretasi adalah memahami dan mengekspresikan makna atau signifikansi dari berbagai macam pengalaman, situasi, data, kejadian-kejadian, penilaian, kebiasaan, atau adat, kepercayaankepercayaan, prosedur atau kriteria-kriteria.

2) Analisis. Analisis adalah mengidentifikasi hubungan-hubugan inferensial yang dimaksud dan aktual diantara pernyataan pernyataan, pertanyaan-pertanyaan, konsep konsep, deskripsi-deskripsi atau bentuk bentuk representasi lainnya yang dimaksudkan untuk mengekspresikan kepercayaan-kepercayaan, penilaian, pengalaman-pengalaman, alasan-alasan, informasi atau opini-opini.

3) Evaluasi. Evaluasi berarti menaksir kredibilitas pernyataan-pernyataan atau representasi-representasi yang merupakan laporan-laporan atau deskripsi-deskkripsi dari persepsi, pengalaman, situasi, penilaian, kepercayaan atau opini seseorang, dan menaksir kekuatan logis dari hubunganhubungan inferensial atau dimaksud diantara pernyataan-pernyataan, deskripsi-deskripsi, pertanyaan-pertanyaan atau bentuk-bentuk representasi lainnya.

4) Inferensi. Inferensi berarti mengidentifikasi dan memperoleh unsur-unsur yang diperlukan untuk membuat kesimpulankesimpulan yang masuk akal, membuat dugaan-dugaan dan hipotesis, mempertimbangkan informasi yang relevan dan menyimpulkan konsekuensi-konsekuensi dari data, situasi-situasi, pertanyaanpertanyaan atau bentuk-bentuk representasi lainnya.

5) Eksplanasi dan Regulasi Diri. Eksplanasi dan regulasi diri berarti menjelaskan apa yang mereka pikir dan bagaimana mereka sampai pada kesimpulan yang telah didapat pada saat inferensi.

\section{Metode}

Penelitian ini merupakan penelitian eksperimen semu. Populasi dalam penelitian ini adalah seluruh siswa kelas VIII SMP Negeri 2 Kendari yang tersebar dalam 9 kelas paralel. Penentuan sampel dalam penelitian ini dilakukan dengan menggunakan teknik purposive sampling, yakni dengan mempertimbangkan rata-rata dan variansi nilai penilaian tengah semester (PTS) yang dimiliki peserta didik pada bidang studi matematika yang relatif sama. Berdasarkan pertimbangan diatas, dipilih dua kelas yakni kelas VIII-C dan VIII-D. Penentuan kelas eksperimen dan kelas kontrol dilakukan secara acak sederhana. Hasil pengacakan diperoleh kelas VIII-D sebagai kelas eksperimen dan kelas VIII-C sebagai kelas kontrol.

Variabel dalam penelitian ini terdiri dari variabel bebas dan variabel terikat. Variabel bebas dalam penelitian ini adalah perlakuan berupa pembelajaran matematika dengan menggunakan model Problem Based Learning $\left(\mathrm{X}_{1}\right)$ di kelas eksperimen dan pembelajaran dengan model pembelajaran langsung $\left(\mathrm{X}_{2}\right)$ di kelas kontrol. Variabel terikat dalam penelitian ini adalah kemampuan berpikir kritis matematis peserta didik (Y).

Model desain yang digunakan dalam penelitian ini adalah model Posttest Only Control Group Design, dimana dua kelas sampel diberikan perlakuan yang berbeda. Adapun desain yang digunakan digambarkan sebagai berikut.

$$
\begin{array}{lll}
\mathbf{R} & \mathbf{X}_{1} & \mathbf{O}_{1} \\
\mathbf{R} & \mathbf{X}_{2} & \mathbf{O}_{2}
\end{array}
$$

Keterangan :

$\mathrm{R}$ = Masing-masing kelas eksperimen dan kelas kontrol dipilih secara Random.

$\mathrm{X}_{1}=$ Pembelajaran matematika dengan model Problem Based Learning

$\mathrm{X}_{2}=$ Pembelajaran matematika dengan model pembelajaran langsung

$\mathrm{O}_{1}=$ Hasil Posttest peserta didik pada kelas eksperimen

$\mathrm{O}_{2}=$ Hasil Posttest peserta didik pada kelas kontrol

Penelitian ini mempunyai dua instrumen yaitu lembar observasi dan tes kemampuan berpikir kritis matematis peserta didik. Lembar observasi digunakan untuk mengukur tingkat aktivitas atau partisipasi guru dan peserta didik dalam proses pembelajaran matematika dengan menggunakan model Problem Based Learning. Dalam penelitian ini digunakan instrumen berupa lembar observasi untuk guru dan untuk peserta didik yang digunakan pada setiap pertemuan. Lembar observasi dibuat oleh peneliti dengan memperhatikan RPP. Lembar observasi yang dibuat terdiri dari beberapa aspek observasi yang bertujuan untuk 
mengamati setiap tindakan/aktivitas yang dilakukan oleh guru dan peserta didik dalam kelas selama proses pembelajaran berlangsung, persiapan materi pembelajaran, serta teknik yang digunakan guru dalam menerapkan model Problem Based Learning. Sedangkan untuk instrumen penelitian berupa tes tertulis dalam bentuk uraian untuk tes akhir (posttest) pada materi sistem persamaan linear dua variabel yang disusun oleh peneliti. Sebelum digunakan, instrumen tersebut dianalisis terlebih dahulu melalui panelis untuk mengetahui validitas dan reliabilitasnya.

\section{Hasil}

\section{Hasil Analisis Deskriptif}

Data yang dianalisis dalam penelitian ini berupa data kuantitatif yang diperoleh dari hasil posttest (tes akhir) kemampuan berpikir kritis matematis peserta didik. Tes ini diberikan kepada 67 orang yang terbagi dalam 2 kelas, yakni 34 orang dari kelas eksperimen dan 33 orang dari kelas kontrol. Data posttest diperoleh dengan memberikan tes mengenai materi Sistem Persamaan Linear Dua Variabel. Namun, sebelum dilakukan posttest, guru melaksanakan kegiatan pembelajaran sebanyak $6 \quad$ kali pertemuan, dengan kelas eksperimen menggunakan model Problem Based Learning, sedangkan kelas kontrol menggunakan model pembelajaran langsung.

\section{Hasil Observasi Pelaksanaab Pembelajaran dengan Menggunakan Model Problem Based Learning oleh Guru}

Hasil observasi terhadap pelaksanaan pembelajaran matematika dengan menggunakan model Problem Based Learning pada materi sistem persamaan linear dua variabel dapat dilihat pada Tabel 2.

Tabel 2.

Deskripsi Keberhasilan Pengelolaan Pembelajaran oleh Guru Pada Kelas Eksperimen

\begin{tabular}{|c|c|c|c|}
\hline Pertemuan & Skor Total & Persentase & Kriteria \\
\hline Pertama & $22 / 25$ & $88 \%$ & Baik \\
\hline Kedua & $22 / 25$ & $88 \%$ & Baik \\
\hline Ketiga & $23 / 25$ & $92 \%$ & Sangat Baik \\
\hline Keempat & $24 / 25$ & $96 \%$ & Sangat Baik \\
\hline Kelima & $23 / 25$ & $92 \%$ & Sangat Baik \\
\hline Keenam & $24 / 25$ & $96 \%$ & Sangat Baik \\
\hline
\end{tabular}

Berdasarkan tabel 2, persentase keberhasilan pengelolaan pembelajaran pada pertemuan pertama mencapai $88 \%$. Pada pertemuan ini, guru masih melakukan penyesuaian terhadap tahap-tahap model problem based learning, demikian pula peserta didik baru mulai untuk beradaptasi dengan model problem based learning. Sehingga langkah-langkah pembelajaran yang direncanakan tidak dapat dilaksanakan, seperti membantu peserta didik melakukan refleksi dan guru tidak sempat memberikan evaluasi untuk dikerjakan peserta didik secara individu akibat alokasi waktu pembelajaran telah habis.

Persentase keberhasilan pengelolaan pembelajaran pada pertemuan kedua masih sama dengan pertemuan pertama yakni $88 \%$. Pada pertemuan kedua ini, kegiatan yang tidak dilakukan oleh guru yakni memberikan evaluasi mandiri kepada peserta didik dan memberikan tugas rumah atau PR. Akan tetapi, pada pertemuan selanjutnya presentase keterlaksanaan terus meningkat hingga 96\%. Hal ini karena guru telah melakukan refleksi terhadap pertemuan-pertemuan sebelumnya dan menyesuaikan alokasi waktu pembelajaran dengan kegiatan pembelajaran di dalam kelas.

\section{Hasil Observasi Aktivitas Peserta Didik dalam Pelaksanaan Pembelajaran dengan Model Problem Based Learning}

Hasil Pengamatan aktivitas peserta didik pada kelas eksperimen selama pembelajaran dapat dilihat pada Tabel 3. 
Tabel 3.

Deskripsi Keaktifan Peserta Didik Kelas Eksperimen

\begin{tabular}{|c|c|c|c|}
\hline Pertemuan & Skor Total & Persentase & Kriteria \\
\hline Pertama & $20 / 25$ & $80 \%$ & Baik \\
\hline Kedua & $20 / 25$ & $80 \%$ & Baik \\
\hline Ketiga & $22 / 25$ & $88 \%$ & Baik \\
\hline Keempat & $22 / 25$ & $88 \%$ & Baik \\
\hline Kelima & $21 / 25$ & $84 \%$ & Baik \\
\hline Keenam & $22 / 25$ & $88 \%$ & Baik \\
\hline
\end{tabular}

Berdasarkan hasil observasi aktivitas peserta didik dalam pelaksanaan pembelajaran matematika menggunakan model problem based learning pada materi sistem persamaan linear dua variabel, pada pertemuan pertama ketercapaian dari seluruh indikator yang diamati adalah $80 \%$ yang berarti bahwa keaktifan peserta didik pada pertemuan pertama tergolong baik. Pada pertemuan pertama, peserta didik antusias dalam mengikuti pembelajaran matematika. Melalui bimbingan guru peserta didik mampu menyelesaikan LKPD yang diberikan. Akan tetapi terdapat indikatorindikator yang tidak dilakukan oleh peserta didik dalam proses pembelajaran. Ketika salah satu perwakilan kelompok mempresentasikan jawaban kelompoknya di depan kelas, peserta didik lainnya terkesan "malu-malu" dalam mengungkapkan ide dan pendapat mereka dalam forum diskusi. Sehingga peneliti bersama guru menilai dalam pelaksanaan pembelajaran dengan model problem based learning, guru harus bisa memastikan bahwa peserta didik melalui tahapan-tahapan pembelajaran dengan bai. Pada pertemuan ini juga, peserta didik tidak sempat mengerjakan soal evaluasi secara mandiri akibat waktu yang telah habis.
Pertemuan kedua, ketercapaian indikator yang diamati yakni $80 \%$ yang berada pada kategori baik. Ketercapaian keseluruhan indikator yang diamati pada pertemuan kedua masih sama pada pertemuan pertama, namun pada tahap ini peserta didik telah melakukan refleksi bersama dengan bimbingan dan arahan dari guru. Pada tahap ini, peserta didik tidak mencatat pekerjaan rumah yang diberikan oleh guru karena pada pertemuan tersebut, guru memang tidak memberikan pekerjaan rumah. Namun, dipertemuan selanjutnya persentase keaktifan peserta didik dalam kelas terus meningkat hingga mencapai $88 \%$.

\section{Hasil Analisis Deskriptif Kemampuan Berpikir Kritis Matematis Peserta Didik pada Kelas Eksperimen dan Kelas Kontrol}

Berdasarkan hasil analisis deskriptif nilai posttest kemampuan berpikir kritis matematis peserta didik menggunakan aplikasi SPSS 21 diperoleh data hasil kemampuan berpikir kritis matematis peserta didik kelas eksperimen dan kelas kontrol yang disajikan pada tabel 4 sebagai berikut.

Tabel 4.

Deskripsi Kemampuan Berpikir Kritis Matematis Kelas Eksperimen dan Kelas Kontrol

\begin{tabular}{|l|c|c|}
\hline \multicolumn{1}{|c|}{ Statistik Deskriptif } & Kelas Eksperimen & Kelas Kontrol \\
\hline Jumlah Sampel & 34 & 33 \\
\hline Mean & 59,56 & 51,52 \\
\hline Median & 59,37 & 56,25 \\
\hline Modus & 81,25 & 68,75 \\
\hline Std. Deviation & 19,95 & 14,91 \\
\hline Variance & 398,28 & 222,24 \\
\hline Skewness & $-0,08$ & $-0,79$ \\
\hline Kurtosis & $-0,947$ & 0,234 \\
\hline Minimum & 25,00 & 12,50 \\
\hline Maximum & 93,75 & 68,75 \\
\hline
\end{tabular}


Berdasarkan tabel 4 terihat bahwa pada kelas eksperimen dengan jumlah sampel 34 orang, nilai rata-rata sebesar 59,56; sedangkan nilai rata-rata kelas kontrol dengan jumlah sampel 33 orang sebesar 51,51. Nilai terendah dan tertinggi pada kelas eksperimen berturutturut sebesar 25,00 dan 93,75; sedangkan nilai terendah dan tertinggi pada kelas kontrol berturut-turut sebesar 12,50 dan 68,75. Modus (nilai yang sering muncul) pada kelas eksperimen sebesar 81,25 dan modus pada kelas kontrol sebesar 68,75. Median (nilai tengah) pada kelas eksperimen sebesar 59,37 dan median pada kelas kontrol sebesar 56,25. Nilai ini menunjukkan bahwa data posttest kemampuan berpikir kritis matematis peserta didik kelas eksperimen lebih tinggi dibandingkan data posttest kemampuan berpikir kritis matematis peserta didik kelas kontrol. Adapun standar deviasi (simpangan baku), varians, skewness dan kurtosis pada kelas eksperimen berturut-turut adalah 19,95; 398,28; $-0,08$ dan $-0,947$ sedangkan standar deviasi, varians skewness dan kurtosis pada kelas kontrol berturut-turut 14,$91 ; 222,24 ;-0,79$ dan 0,234 . Hal ini menunjukkan bahwa kemampuan berpikir kritis matematis peserta didik kelas eksperimen lebih beragam dibandingkan dengan kemampuan berpikir kritis matematis peserta didik kelas kontrol.

Distribusi nilai kemampuan berpikir kritis matematis peserta didik kelas eksperimen dan kontrol ditampilkan pada Tabel 5 sebagai berikut.

Tabel 5.

Distribusi Nilai Kemampuan Berpikir Kritis Matematis Peserta Didik yang Diajar dengan Model Problem Based Learning dan Diajar dengan Model Pembelajaran Langsung

\begin{tabular}{|l|c|c|c|c|}
\hline \multirow{2}{*}{ Kategori } & \multicolumn{2}{|c|}{ Model } & \multicolumn{2}{c|}{ Model } \\
& \multicolumn{2}{|c|}{ Problem Based Learning } & Pembelajarang Langsung \\
\cline { 2 - 5 } & Frekuensi & Persentase (\%) & Frekuensi & Persentase (\%) \\
\hline Sangat Tinggi & 2 & 5,88 & 0 & 0 \\
\hline Tinggi & 10 & 29,42 & 7 & 21,21 \\
\hline Sedang & 12 & 35,29 & 14 & 42,42 \\
\hline Rendah & 7 & 20,59 & 10 & 30,30 \\
\hline Sangat Rendah & 3 & 8,82 & 2 & 6,07 \\
\hline Jumlah & 34 & 100 & 33 & 100 \\
\hline
\end{tabular}

Berdasarkan Tabel 5 dapat dilihat bahwa distribusi nilai posttest pada kelas eskperimen tersebar pada kategori sangat tinggi, tinggi, hingga sangat rendah. Sebanyak dua peserta didik berada pada kategori sangat tinggi dan sepuluh peserta didik pada kategori tinggi. Sedangkan sisanya tersebar pada kategori sedang hingga sangat rendah. Tetapi pada kelas kontrol, tidak ada satupun peserta didik yang berada pada kategori sangat tinggi. Semua peserta didik tersebar pada kategori tinggi, sedang hingga sangat rendah. Diagram distribusi data kemampuan berpikir kritis peserta didik sebagaimana ditunjukkan pada gambar 1 .

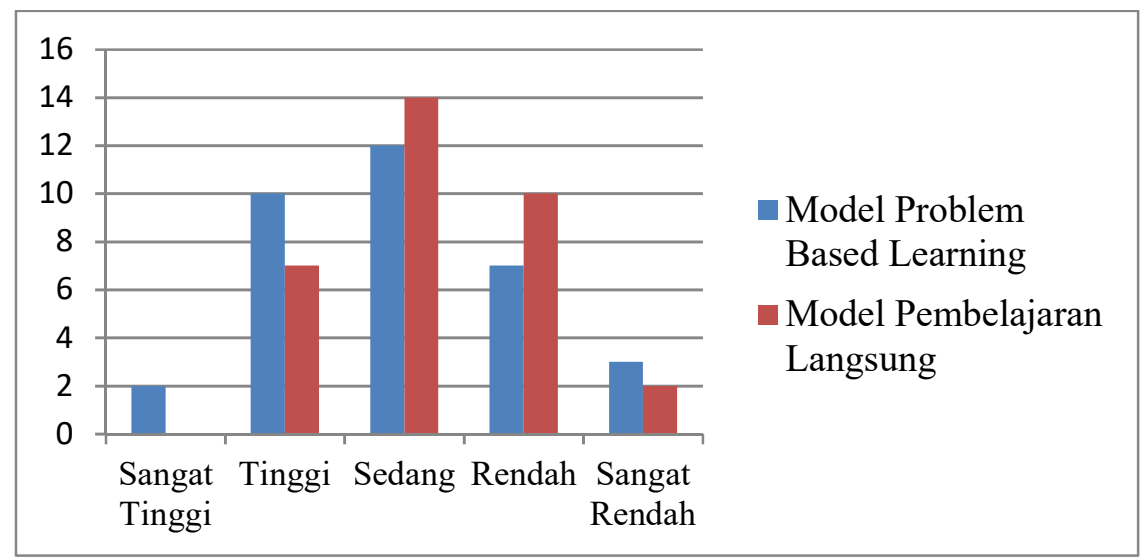

Gambar 1. Distribusi Data Kemampuan Berpikir Kritis Matematis 


\section{Hasil Analisis Inferensial}

Analisis yang digunakan dalam penelitian ini adalah uji hipotesis dengan uji-t. Melalui analisis inferensial, kita dapat mengetahui apakah hipotesis dalam penelitian ini diterima atau ditolak. Terdapat beberapa tahap analisis yang menjadi prasyarat untuk melakukan analisis uji hipotesis yaitu analisis uji normalitas data dan analisis uji homogenitas data. Uji normalitas data dimaksudkan untuk mengetahui apakah data berasal dari populasi yang berdistribusi normal atau tidak, sedangkan uji homogenitas dimaksudkan untuk mengetahui apakah data yang diperoleh homogen terhadap populasinya atau tidak, setelah melalui syarat uji normalitas dan homogenitas maka dilanjutkan dengan uji hipotesis. Berikut penjabaran dari tahap analisis inferensial.

\section{Uji Normalitas}

Uji normalitas digunakan untuk mengetahui apakah data kemampuan berpikir kritis matematis kedua kelas berdistribusi normal atau tidak. Untuk menguji apakah data berdistribusi normal atau tidak digunakan statistik uji Kolmogorov Smirnov dengan menggunakan bantuan aplikasi IBM SPSS Statistics 21. Dalam analisis ini digunakan nilai posttest kelas eksperimen dan kelas kontrol. Pengambilan keputusan untuk normalitas data adalah sebagai berikut :

$\mathrm{H}_{0}$ : Data berdistribusi normal

$\mathrm{H}_{1}$ : Data tidak berdistribusi normal,

Dengan kriteria pengujian :

$\mathrm{H}_{0}$ diterima, jika nilai Asymp. Sig. (2-tailed) $>\alpha$ $(0,05)$

Adapun hasil analisisnya dapat dilihat pada tabel 6 berikut.

Tabel 6.

Hasil Analisis Uji Normalitas Data Posttest

\begin{tabular}{|c|c|c|}
\hline Kelas & Sig. (2-tailed) & Keputusan \\
\hline Eksperimen & 0,38 & Terima Ho \\
\hline Kontrol & 0,54 & Terima Ho \\
\hline
\end{tabular}

Berdasarkan hasil analisis perhitungan uji normalitas diperoleh untuk kelas eksperimen nilai Asymp. Sig. (2-tailed) $=0,38>0,05=\alpha$ maka $\mathrm{H}_{0}$ diterima. Hal ini berarti bahwa data posttest kemampuan berpikir kritis matematis peserta didik pada kelas eksperimen berdistribusi normal. Sedangkan untuk kelas kontrol diperoleh nilai Asymp. Sig. (2-tailed) $=$ $0,54>0,05=\alpha$ maka $\mathrm{H}_{0}$ diterima. Hal ini berarti bahwa data posttest kemampuan berpikir kritis matematis peserta didik pada kelas kontrol berdistribusi normal.

\section{Uji Homogenitas Varians}

Uji homogenitas varians digunakan untuk mengetahui apakah varians dari kedua kelompok data posttest kemampuan berpikir kritis matematis peserta didik homogen atau tidak. Berdasarkan hasil uji homogenitas varians data dari kedua kelompok sampel dengan bantuan IBM SPSS Statistics 21, hasil perhitungan dapat dilihat pada Tabel 7.

Tabel 7.

Hasil Analisis Uji Homogenitas Varians Data Posttest

\begin{tabular}{|l|l|}
\hline Sig. & Keputusan \\
\hline 0,06 & Terima Ho \\
\hline
\end{tabular}

Berdasarkan hasil analisis uji homogenitas varians diperoleh nilai $\mathrm{Sig}=0,06$. Karena nilai $\mathrm{Sig}=0,06>0,05=\alpha$ maka $\mathrm{H}_{0}$ diterima, hal ini berarti bahwa data yang diperoleh memiliki varians yang homogen.

\section{Uji Hipotesis}

Pengujian hipotesis menggunakan uji-t data sampel saling bebas (Independent Sample t-test) dilakukan dengan rumus uji-t menggunakan IBM SPSS Statistics 21. Hipotesis yang akan di uji kebenarannya dalam penelitian ini adalah "Terdapat pengaruh yang signifikan model Problem Based Learning terhadap kemampuan 
berpikir kritis matematis peserta didik kelas VIII SMP Negeri 2 Kendari."

Hipotesis statistik dirumuskan sebagai berikut:

Kriteria:

$$
\mathrm{H}_{0}: \mu_{1} \leq \mu_{2} \quad \text { vs } \quad \mathrm{H}_{1}: \mu_{1}>\mu_{2}
$$

Terima $\mathrm{H}_{0}$ jika $\mathrm{t}<\mathrm{t}_{\text {(tabel) }}$, dimana $d f=\left(\mathrm{n}_{1}+\mathrm{n}_{2}-\right.$

2). Untuk harga-harga t lainnya $\mathrm{H}_{0}$ ditolak.

Kriteria uji dengan SPSS:
Jika nilai $\frac{\text { Sig.(2-tailed) }}{2} \geq \alpha=0,05$, maka $\mathrm{H}_{0}$ diterima.

Jika nilai $\frac{\text { Sig.(2-tailed) }}{2}<\alpha=0,05$, maka $\mathrm{H}_{0}$ ditolak

Adapun hasil analisis uji hipotesis dapat dilihat pada Tabel 8 berikut.

Tabel 8.

Hasil Analisis Uji Hipotesis

\begin{tabular}{|c|c|c|}
\hline$t$ hitung & $\frac{\text { Sig }(2-\text { tailed })}{2}$ & Keputusan \\
\hline 1,86 & 0,03 & Tolak Ho \\
\hline
\end{tabular}

Berdasarkan hasil analisis uji-t diperoleh $\mathrm{t}_{\text {hitung }}=$ $1,86>\mathrm{t}_{\text {tabel }}=1,66$ atau nilai $\frac{\operatorname{Sig}(2-\text { tailed })}{2}=0,03$ $<0,05$; maka $\mathrm{H}_{0}$ ditolak.

\section{Pembahasan}

Terdapat faktor yang dapat menyebabkan rendahnya kemampuan berpikir kritis matematis peserta didik, salah satunya adalah penggunaan model pembelajaran yang kurang inovatif. Model pembelajaran yang dapat digunakan untuk membantu peserta didik terkait kemampuan berpikir kritis matematis adalah model Problem Based Learning atau pembelajaran berbasis masalah.

Kegiatan pembelajaran dengan model Problem Based Learning di kelas eksperimen dimulai dengan tahap pendahuluan, yakni guru membuka pelajaran dan menginformasikan topik pembelajaran yang akan dibahas, pemberian apersepsi dan motivasi kepada peserta didik agar peserta didik antusias dalam belajar di kelas. Pada tahap orientasi peserta didik pada masalah, guru menjelaskan tujuan pembelajaran dan memperlihatkan masalah kontekstual kepada peserta didik. Kemudian pada tahap mengorganisasikan peserta didik untuk belajar, guru membagi peserta didik menjadi kelompok heterogen. Kemudian masing-masing kelompok diberikan LKPD untuk didiskusikan dan diselesaikan secara berkelompok. Pada tahap membimbing individu atau kelompok, guru berperan memberi pengarahan dan bimbingan kepada peserta didik melalui penjelasan atau pertanyaan yang mengarah kepada penyelesaian masalah. Setelah semua kelompok mengerjakan LKPD sesuai waktu yang ditetapkan, pada tahap menyajikan hasil karya, beberapa peserta didik dipilih untuk mewakili kelompoknya untuk mempresentasi hasil kerja kelompoknya dan ditanggapi oleh kelompok lain. Guru berperan memandu jalannya diskusi, meluruskan jika terdapat jawaban keliru dan membantu peserta didik dalam mengambil kesimpulan jawaban yang benar. Diakhir pembelajaran, guru mengajak peserta didik untuk melakukan refleksi dan evaluasi terhadap pembelajaran yang dilakukan. Terakhir, guru memberi tugas untuk dikerjakan di rumah secara individu.

Selama enam kali tatap muka pada proses pembelajaran dengan model Problem Based Learning pada kelas eksperimen, diperoleh tingkat keaktifan peserta didik dalam mengikuti pembelajaran terkategori baik. Pada pertemuan pertama dan kedua keaktifan peserta didik terkategori baik sebab peserta didik secara aktif menyelesaikan permasalahan yang diberikan dalam LKPD secara berkelompok. Walaupun mereka masih merasa kesulitan dalam menyelesaikan LKPD, namun mereka aktif bertukar pikiran dengan teman kelompoknya dan selalu bertanya kepada guru. Namun, ketika presentasi dilakukan, mereka masih terkesan malu-malu untuk mengungkapkan ide masingmasing. Pada pembelajaran ketiga dan keempat persentase perolehan keaktifan peserta didik berdasarkan lembar observasi mengalami peningkatan. Ketercapaian pada pertemuan ketiga dan keempat terkategori baik. Pada pertemuan ketiga dan keempat ini peserta didik mulai terbiasa menuliskan secara individu gambaran solusi dari suatu permasalahan, peserta didik juga mulai terbiasa belajar secara berkelompok dengan menggunakan model problem based learning. Mereka terus terlibat 
aktif dalam kelompok serta antusias bertanya dan mengikuti proses pembelajaran. Terlihat bahwa peserta didik sering bertanya saat mengidentifikasi penyebab masalah dan saat mendeteksi solusi dari masalah yang ada dan mereka mampu menemukan solusi dari suatu permasalahan yang ada.

Pada pertemuan kelima, persentase tingkat keaktifan peserta didik menurun, Salah satu penyebab tingkat keaktifan peserta didik menurun pada pertemuan kelima adalah karena peserta didik tidak sempat mencatat tugas rumah yang diberikan oleh guru (peneliti). Seharusnya pada pertemuan kelima, peneliti memberikan tugas rumah kepada peserta didik. Akan tetapi, berdasarkan hasil diskusi peneliti dengan guru kelas VIII-D untuk tidak memberikan tugas rumah agar peserta didik tidak terlalu terbebani karena setiap pertemuan selalu diberikan tugas. Namun dipertemuan terakhir, persentase keaktifan peserta didik kembali meningkat.

Berdasarkan hasil analisis deskriptif dari data hasil posttest yang telah diperoleh, nilai rata-rata kelas eksperimen lebih tinggi dibandingkan dengan nilai rata-rata kelas kontrol. Berdasarkan nilai rata-rata, maka kemampuan berpikir kritis matematis peserta didik kelas eksperimen lebih tinggi dari kemampuan berpikir kritis matematis peserta didik kelas kontrol. Hal ini mengindikasikan bahwa dari indikator nilai rata-rata, model Problem Based Learning mampu memberi pengaruh yang positif dalam meningkatkan kemampuan berpikir kritis matematis peserta didik jika dibandingkan dengan model pembelajaran langsung. Dari indikator keragaman data (varians), data posttest kelas eksperimen memiliki varians yang lebih besar dibandingkan dengan data posttest kelas kontrol. Nilai varians dari kedua kelompok tersebut menunjukkan bahwa kemampuan berpikir kritis matematis peserta didik kelas eksperimen lebih beragam daripada kelas kontrol. Sedangkan dari indikator skewness, kedua kelas memiliki nilai skewness yang hampir sama, akan tetapi nilai kemampuan berpikir kritis matematis pada kelas kontrol lebih banyak yang memperoleh nilai di atas rata-rata daripada kelas eksperimen. Adapun berdasarkan indikator nilai maksimum, nilai minimum, modus dan media, data hasil posttest kemampuan berpikir kritis matematis peserta didik kelas eksperimen lebih tinggi daripada data hasil posttest peserta didik kelas kontrol. Sehingga secara umum dapat dikatakan bahwa kemampuan berpikir kritis matematis peserta didik kelas eksperimen yang diajar dengan model problem based learning lebih baik daripada kemampuan berpikir kritis matematis peserta didik kelas kontrol yang diajar dengan model pembelajaran langsung.

Ada beberapa hal yang menyebabkan nilai kelas eksprimen lebih tinggi dari kelas kontrol. Pada pembelajaran di kelas kontol, pembelajaran berpusat pada guru dan model pembelajaran langsung yang diterapkan adalah model pembelajaran yang cukup sering digunakan oleh guru di sekolah, sehingga murid terkesan bosan dan beberapa murid yang duduk di bagian belakang kerap bermain terutama saat guru memberikan soal kepada peserta didik untuk dikerjakan.

Pembelajaran di kelas eksperimen jauh lebih baik dari pada kelas kontrol, meskipun ada sedikit gangguan-gangguan kecil yang dihadapi contonya seperti beberapa peserta didik yang memilih diam saat ditanya atau tidak mau memberikan pendapat, namun karena guru menggunakan model Problem Based Learning yang pembelajaran tidak berpusat pada guru, sehingga peserta didik lebih dituntut aktif. Selain itu, peserta didik dikelas ekseprimen banyak diantaranya yang mengerjakan LKPD dengan sungguh-sungguh dan berdasarkan apa yang mereka pahami. Hal-hal itulah yang menjadi alasan atau penyebab mengapa kemampuan berpikir kritis matematis peserta didik di kelas eksperimen tergolong lebih baik dari peserta didik di kelas kontrol yang di ajar dengan menggunakan model pembelajaran langsung.

Penolakan Ho menunjukkan bahwa model Problem Based Learning mempunyai pengaruh lebih baik secara signifikan terhadap kemampuan berpikir kritis matematis peserta didik kelas VIII SMP Negeri 2 Kendari. Adanya pengaruh kemampuan berpikir kritis matematis ini terjadi karena adanya pembelajaran dengan menggunakan model Problem Based Learning. Hal ini sesuai dengan teori yang disampaikan oleh Husnidar, dkk bahwa model Problem Based Learning menghadapkan peserta didik pada suatu masalah yang kemudian melalui pemecahan masalah peserta didik belajar keterampilan-keterampilan berpikir, yakni keterampilan berpikir kritis. Hal tersebut juga didukung oleh teori yang dikemukakan oleh 
Kurniasih dan Berlin bahwa salah satu dari tujuan dari model Problem Based Learning adalah membantu peserta didik mengembangkan keterampilan berpikir yakni keterampilan berpikir kritis dan keterampilan berpikir kreatif. Selain itu, berdasarkan penelitian terdahulu yang dilakukan oleh Sujana (2013) dan Yuni (2017) yang sama-sama menyimpulkan bahwa model Problem Based Learning dapat meningkatkan kemampuan berpikir kritis peserta didik.

Keberhasilan pelaksanaan pembelajaran dengan model Problem Based Learning dan hasil posttest kemampuan berpikir kritis juga merupakan faktor yang mempengaruhi mengapa penelitian ini dapat berhasil. Ditinjau dari keberhasilan pembelajaran, persentase ketercapaian pembelajaran berkisar dari $88 \%$ hingga 96\% yakni pada kategori baik hingga sangat baik. Sedangkan tingkat partisipasi keaktifan peserta didik dalam pembelajaran mencapai persentase $80 \%$ hingga $88 \%$. Ditinjau dari hasil posttest yang bertujuan untuk mengukur kemampuan berpikir kritis matematis peserta didik, rata-rata posttest kelas eksperimen lebih tinggi daripada rata-rata posttest kelas kontrol. Hal ini menunjukkan bahwa model Problem Based Learning mempunyai pengaruh positif terhadap kemampuan berpikir kritis matematis peserta didik.

Model Problem Based Learning ini mendorong peserta didik untuk berpikir secara kelompok maupun individu, berperan aktif dalam pembelajaran dan mampu memecahkan masalah serta dapat menarik sebuah kesimpulan/solusi yang tepat dari suatu masalah. Dengan demikian, peserta didik lebih terlatih lagi dalam memecahkan suatu masalah ataupun menarik kesimpulan/solusi yang tepat. Kenyataan yang diperoleh dalam penelitian ini terdapat pengaruh penggunaan model Problem Based Learning terhadap kemampuan berpikir kritis matematis peserta didik atau menginformasikan bahwa penggunaan model Problem Based Learning lebih baik daripada penggunaan pembelajaran langsung terhadap kemampuan berpikir kritis matematis peserta didik. Selain itu, model Problem Based Learning ini dapat dijadikan sebagai salah satu pertimbangan bagi guru untuk diterapkan sebagai salah satu alternatif untuk membantu peserta didik dalam meningkatkan kemampuan berpikir kritis matematis peserta didik.

\section{Simpulan dan Saran}

\section{Simpulan}

Berdasarkan hasil penelitian dan pembahasan dalam penelitian ini, maka dapat dikemukakan beberapa kesimpulan sebagai berikut :

1. Proses pembelajaran dengan menggunakan model Problem Based Learning pada kelas VIII SMP Negeri 2 Kendari terkategori baik hingga sangat baik. Secara keseluruhan persentase tingkat keterlaksanaan pembelajaran oleh guru pada 6 kali pertemuan berturut-turut adalah $88 \%, 88 \%$, $92 \%$, 96\%, 92\%, dan 96\%. Sedangkan persentase tingkat keaktifan peserta didik pada 6 kali pertemuan berturut-turut adalah $80 \%, 80 \%, 88 \%, 88 \%, 84 \%$, dan $88 \%$.

2. Gambaran kemampuan berpikir kritis matematis peserta didik kelas VIII-D SMP Negeri 2 Kendari yang diajar dengan menggunakan model Problem Based Learning pada pokok bahasan sistem persamaan linear dua variabel diperoleh nilai rata-rata 59,55; standar deviasi 19,95; varians 398,28 ; skewness $-0,08$; kurtosis $-0,94$; median 59,37; modus 81,25 ; nilai minimum 25,00; dan nilai maksimum 93,75.

3. Gambaran kemampuan berpikir kritis matematis peserta didik kelas VIII-C SMP Negeri 2 Kendari yang diajar dengan menggunakan pembelajaran langsung pada pokok bahasan sistem persamaan linear dua variabel diperoleh nilai rata-rata 51,52; standar deviasi 14,91; varians 222,24; skewness $-0,79$; kurtosis 0,234 ; median 56,25 ; modus 68,75 ; nilai minimum 12,50 ; dan nilai maksimum 68,75 .

4. Terdapat pengaruh yang signifikan model Problem Based Learning terhadap kemampuan berpikir kritis matematis peserta didik di kelas VIII SMP Negeri 2 Kendari.

\section{Saran}

Dari hasil penelitian ini dapat disarankan beberapa hal sebagai berikut:

1. Kepada para guru yang mengajar mata pelajaran matematika sekiranya dapat menggunakan model Problem Based Learning dalam pembelajaran matematika untuk mengoptimalkan kemampuan berpikir kritis matematis peserta didik. 
2. Dengan adanya beberapa keterbatasan dalam penelitian ini, sebaiknya dilakukan penelitian yang lebih lanjut untuk meneliti tentang pembelajaran dengan model Problem Based Learning pada pokok bahasan yang cocok atau pada jenjang sekolah yang berbeda.

\section{Daftar Pustaka}

Amir, T. (2010). Inovasi Pendidikan Melalui Problem Based Learning. Jakarta: Kencana Prenada Media Group.

Arends, R.I. (2012). Learning to Teach $\left(9^{\text {th }}\right.$ ed). New York, NY: Mc Graw Hill Companies.

Hendriana, H., Rohaeti, E.E., dan Utari S. (2017). Hard Skills dan Soft Skills Matematik Siswa. Bandung: Refika Aditama.

Husnidar., Ikhsan, M., dan Syamsul R. (2014). Penerapan Model Pembelajaran Berbasis Masalah untuk Meningkatkan Kemampuan Berpikir Kritis dan Disposisi Matematika Siswa. Jurnal Didaktik Matematika. 1(1), $71-82$.

Junaidi. (2017). Analisis Kemampuan Berpikir Kritis Matematis Siswa dengan Menggunakan Granded Response Models di SMA Negeri 1 Sakti. ISSN 2355-0074. 1(4), $14-25$.

Karim dan Normaya. (2015). Kemampuan Berpikir Kritis Matematis Siswa dalam Pembelajaran Matematika dengan Menggunakan Model Jucama di Sekolah Menengah Pertama. Jurnal Pendidikan Matematika. 1(3), $92-104$

Kurniasih, I., dan Berlin S. (2017). Ragam Pengembangan Model Pembelajaran Untuk Peningkatan Profesionalitas Guru. Jakarta: Kata Pena.

Lestari, K.E. (2013). Implementasi Brain Based Learning untuk Meningkatkan Kemampuan Koneksi dan Kemampuan Berpikir Kritis Matematis Siswa Sekolah Menengah Pertama. Tesis Sekolah Pascasarjana. UPI: Bandung.

Nahdi, D.S. (2015). Meningkatkan Kemampuan Berpikir Kritis dan Penalaran Matematis Siswa Melalui Model Brain Based Learning. Jurnal Cakrawala Pendas. 1(1), 13 - 24.

Saleh, M. (2013). Strategi Pembelajaran Fiqh dengan Problem-Based Learning. Jurnal Ilmiah DIDAKTIKA. 14(1), $190-220$.

Sujana, R., dan Utu R. (2013). Peningkatan Kemampuan Berpikir Kritis Matematis Siswa Kelas XI IPA SMA Negeri 1 Kendari Melalui Pembelajaran Berbasis Masalah. Jurnal Penelitian Pendidikan Matematika. 1(1), 61 - 76. 